\title{
Geology and Lamongan Volcanic Rocks \\ Case Study at Ranu Pakis, Klakah, Lumajang, East Java Province, Indonesia
}

\author{
Dwi Fitri Yudiantoro ${ }^{*}$, Ramonada Taruna Perwira', Muchamad Ocky Bayu Nugroho \\ ${ }^{1}$ Geological Engineering of UPN Veteran Yogyakarta University, Indonesia.
}

*Corresponding author : d_fitriyudiantoro@upnyk.ac.id

Tel.:+62-8122964012

Received: Dec 21, 2018, Accepted: Nov 12, 2019.

DOI: 10.25299/jgeet.2019.4.4.2456

\section{Abstract}

Lamongan volcano is one of the unique volcanoes in the Sunda Volcano. This volcano has side eruption centers or on the slopes of the volcano. The morphology of parasitic eruptions in this volcanoes complex includes maars and boccas. There are about 64 parasitic eruption centers consisting of 37 volcanic cones (bocca) and 27 ranu (maar).

The purpose of this research is to study the characteristics of lithology and petrogenesis of this volcano complex, especially in Ranu Pakis and surrounding areas. The analytical method used is to do geological mapping and petrographic analysis.

The lithology found in this research area consists of magmatic and phreatomagmatic eruption deposits. Genetically this lithology includes pyroclastic flow, pyroclastic fall (scoria fall and phreatomagmatic scoria fall/accretionary lapili), tuff (phreatic) and basaltic lava. In some pyroclastic deposits, especially in maar there are fragments of accretionary lapilli, while in bocca there are basaltic lavas. Other fragments present in pyroclastic deposits are basalt scoria blocks and bombs embedded in the groundmass of volcanic ash. The results of petrographic analysis indicate that the volcanic rocks in the study area are calc alkaline affinity consisting of pyroxene andesite, basalt and pyroxene basalt lava. The pyroxene basalt lava is composed by plagioclase, clinopyroxene and little olivine embedded in the volcanic glass. Lavas are structured scoria and textured porphyritic, intersertal, trachytic, aphyric and pilotaxitic. Trachytic texture is found in the basalt fragments of pyroxene from the pyroclastic fall deposits in Ranu Pakis and Ranu Wurung. While pyroxene andesite lavas composed by plagioclase, clinopyroxene embedded in the volcanic glass. Lavas are structured scoria and textured porphyritic, intergranular, pilotaxitic and aphyric.

Keywords: Lamongan, maar, bocca, pyroclastic, accretionary lapilli, basalt

\section{Introduction}

Indonesia is one of the countries passed by ring off fire path. Along this path there are active or inactive clusters of volcanoes. Indonesia has 129 volcanoes where 35 of them are located in Java Island and one of them is Lamongan volcano.

Lamongan volcano is a unique volcano. Many of these volcanic eruption centers do not occur at the center of the diatrem pipe, but the eruption center is on the side or slopes of the volcano. There are about 64 parasitic eruption centers consisting of 37 volcanic cones and 27 "maars" (Matahelumual, 1960). Of the 27 ranus there are 13 of them filled with water, such as Ranu Klakah, Ranu Pakis, Ranu Bedali, Ranu Lading etc. (Matahelumual, 1990).

Maar is a manifestation of phreatomagmatic eruption that has a close relationship with the activities of hydrovolcanism. (Sheridan and Wohletz, 1983). Hydroclastic eruptions occur, when magma or heat sources contact with meteoric water (indirectly) at the time of the eruption. These characteristics make this volcano unique because when this volcano erupts, it will find hydroclastic eruption products such as accretionary lapilli and armored lapilli. Another geological aspect that makes this volcano different is that Lamongan Volcano is a volcano with a basaltic composition. According to Schieferdecker (1959), maar is a basin generally filled with water $2 \mathrm{~km}$ in diameter, and surrounded by deposit eruption. Maar is also referred to as monogenic volcanic cone which cuts the bedrock beneath the surface of the groundwater and forms a gently sloped cone which is composed by finegrained volcanic deposits, having a crater diameter variation of 100-3,000 $\mathrm{m}$ filled by water to form a lake (Bronto, 2001; Cas and Wright, 1988).

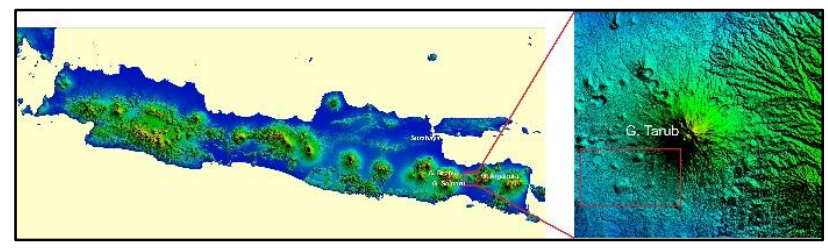

Fig 1. Location of Reseacrh Area 
The research area is located in the Lamongan volcano complex, which is in Ranu Pakis and surrounding areas, Lumajang Regency, East Java Province. This area is about $16 \mathrm{~km}$ to the northeast of Lumajang City, East Java (Figure 1).

\section{Data and Methodology}

This study aims to study the characteristics of lithology and magmatism of Lamongan volcano complex, especially in Ranu Pakis and surrounding areas. The analytical method used is by doing geological mapping and petrographic analysis. The thin section were performed on 3 samples of pyroclastic fall fragments and 12 lava samples (basalt, pyroxene basalt and pyroxene andesite) which are expected to be representative for explaining the petrogenesis of volcanic rocks in the study area.

Petrographic analysis was done by observing mineralogy of volcanic rock composite from thin section. Using a polarizing microscope to determine the structure, texture and mineral composition. The results of the analysis are used to determine the type of rock, magma affinity and tectonic environment.

\section{Result and Discussion}

\subsection{Geological Setting}

Geologically Java Island is a formation caused by the process of collision of Eurasia Continental Plate and Indian-Australia Ocean Plate that has been going on since Eocene and still happens until now. The collision between the plates is a frontal subduction/perpendicular. The collision of these plates produces volcanic arcs and subduction zones or trenches, and has been going on since the CretaceousPaleocene. The Cretaceous subduction zone is represented by the Melange Luk Ulo-Karangsambung complex, Kebumen (Asikin, 1974; Hamilton, 1979; Suparka, 1988; Parkinson et al., 1998) that have a general direction of northeast-southwest structure and continuously toward the Meratus Mountains at the southeast end of Borneo.

The pattern of alignment of the geological structure of Java Island by Pulunggono and Martodjojo (1994) can be divided into 3 direction of straightness, ie: Meratus pattern of northeast-southwest direction, Sunda pattern north-south direction, and Java pattern east-west direction. According to Soeria-Atmadja et al. (1994) the subduction zone can be identified from the resulting magmatic arcs: the west-east-trending magmatic arc of tholeiitic-calc alkaline so called Old Andesite volcanic formation (Late Eocene-Early Miocene). This magmatic arc has an east-west direction which is an calk-alkaline affinity that has the Late Miocene-Pliocene age. The trending of the active magmatic arc is west-east and had Quaternary volcanoes. The Tertiary magmatic arc grows alongside, while the Quaternary magmatic arc grows on the above the Miosen-Pliocene magmatic arc.

The Lamongan volcano is physiographically located in the Quaternary volcanic arc. Volcanic arc is composed by a range of young strato volcano (Bemmelen, 1949). At the Lamongan volcano formed many cinder cones and maars (Carn 2000; Carn and
Pyle 2001). Maars and cinder cones formed when magmas came in contact with water, causing a phreatomagmatic eruption associated with pyroclastic fall and flow deposits (Heiken 1971). Some of the maars in the Lamongan area are NW-SE oriented comparable with the strike of the Tiris fault (Carn, 1999).

The Lamongan volcano is located in a structurally complex area and was very active until approximately 14,000 years ago. The volcano is composed of three different events: Tarub, Cupu and Lamongan itself (Carn 1999). Tarub is the oldest cone and detached from the younger stratocone of Lamongan by a prominent NW-SE depression, which is most likely fault related. Bronto et.al. (1986) divided Lamongan volcano eruption based on eruption center position, namely: central eruption, side eruption and outer center/parasitic eruption. This volcano lithology comprises consolidated and unconsolidated materials including: olivine basalt lava, pyroxene basalt lava, basaltic andesitic lava, basalt lava, pyroclastic deposit with lapilli-bomb scoria fragments (basalt, andesit basaltic) and lava. Matahelumual (1990) explains that from the beginning to the end of the 19th century, based on the density levels of lava and lava flow, the Lamongan volcano is the mostly active volcano in Indonesia. This volcano produces phreatic, magmatic and phreatomagmatic eruptions. The three types of eruptions can occur at the time of maar formation. Magmatic eruptions in history occur in the Lamongan crater and side crater, while the Tarub crater and parasitic cones occur at pre-historic times. Some types of eruptions can be categorized as strombolian and volcanian eruption types.It is requested not to us any of footnotes. All references should be in the References. Explanations should be preferably included in the text.

\subsection{Lithostratigraphy of Ranu Pakis and Surrounding Area}

Based on the results of mapping during the field both from the observation of physical characteristics and variations of lithology, the unit of volcanic rock lithostratigraphy at research area can be grouped into Tarub volcanic eruption deposits and Lamongan volcanic eruption deposits. The Tarub volcanic eruption deposits are the oldest deposit consisted of pyroclastic Tarub unit (Tp), maar Tarub unit (Tma) and Tarub eccentric eruption unit (Tel). While Lamongan volcanic eruption deposits include Lamongan old lava unit (Lit), Lamongan pyroclastic deposit unit (Lp), Lamongan volcano's old flank eruption lava unit (List) and Lamongan volcano's young flank eruption lava unit (Lism). The distribution of each rock units are presented on the geological map of Ranu Pakis and surrounding area (Figure 12).

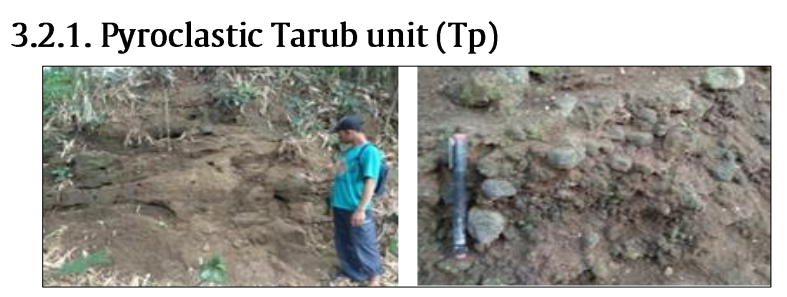

Fig 2. Tarub pyroclastic fall deposit (Tp) at Ranu Pakis village. 
The Tarub pyroclastic deposit unit (Tp) is the oldest unit and this pyroclastic deposits are the result of the central eruption. This unit consists of pyroclastic fall deposits. The pyroclastic fall deposits are brownish, lapilli-block/bomb (2-64mm) grain size, angular shape and embedded in volcanic ash $(<0.1-0.3 \mathrm{~cm})$. The fragments consist of: armored lapilli (scoria basalt), block and bombs, well sorted, showing the bedding structure and graded bedding. The outcrops condition are not consolidated and weathered moderately (Figure 2).

\subsubsection{Maar Tarub unit (Tma)}

The maar Tarub unit is a pyroclastic deposit resulting from the side eruption of the Tarub volcano and the lithologic unit found around the ranu (crater lake). The unit consists of maar Ranu Pakis deposit, maar Ranu Wurung deposit, maar Ranu Lading lava, and maar Ranu Kembar lava. This maar deposits are composed by pyroclastic fall deposit, tuff, lava and deposited around the ranu (crater lake). Yudiantoro and Yudiantoro (1992) explained that the maar Ranu Parang deposit which is also part of the maar of Lamongan complex. These deposits consist of hydroclastic deposit as accretionary lapilli fragments, vitric shard, armored lapilli and accidental clast embedded in a fine grained volcanic ash. The sedimentary structures found are vesicle bending sags and bad sorting.

\subsubsection{Maar Ranu Pakis deposit}

This maar deposit is consists of pyroclastic fall deposits and tuffs. The pyroclastic fall deposits are brownish, lapilli-block/bomb size (2-64mm), unrounded. The fragments composed by basalt and armored lapilli embedded in a matrix of volcanic ash, disaggregated well and has a structure of sedimentary is graded bedding. Tuffs are brown, fine dust sized $(<0,04 \mathrm{~mm})$, massive bedding structures, medium weathered and found in Ranu Pakis village (Figure 3).

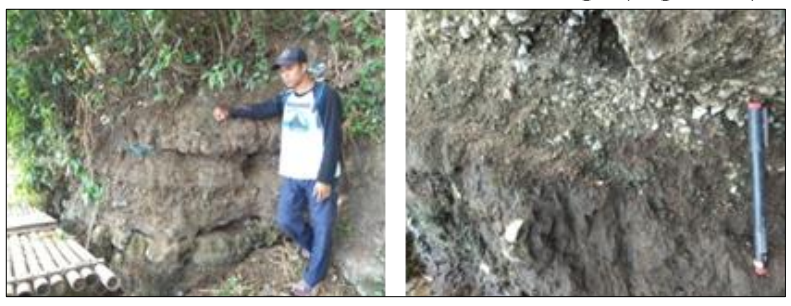

Fig 3. The Ranu Pakis deposits outcrop composed by pyroclastic fall deposit with fragments composed by basalt and armored lapilli scoria embedded in a volcanic ash matrix. It appears that the sedimentary structure was graded bedding and founded in Ranu Pakis village.

\subsubsection{Maar Ranu Wurung Deposit}

This maar deposits are composed by pyroclastic fall (scoria fall), brownish color, a lapilli-bomb/block (2$64 \mathrm{~mm}$ ) fragment embedded in a volcanic ash matrix. The shape of fragments are subrounded-angular and type of scoria basalt. Well sorted and the sedimentary structure was graded bedding and founded in Ranu Wurung. The outcrops are unconsolidated, and weathered moderately. Sayudi (1990) explains that maar Ranu Wurung is a ranu that is not watery. At the bottom is the basalt lava and above it deposited magmatic deposits (scoria fall) and phreatic deposits.

\subsubsection{Maar Ranu Lading Lava}

This Ranu is composed by pyroxene basalt lava. In the megascopic of lava basalt pyroxene shows grayblack, massive structure, hypocrystalline, medium feneric granularity. The observable mineral compositions include plagioclase, pyroxene and olivine embedded in volcanic glass groundmass. This basaltic lava outcrop is present at Ranu Lading. (Figure 4).

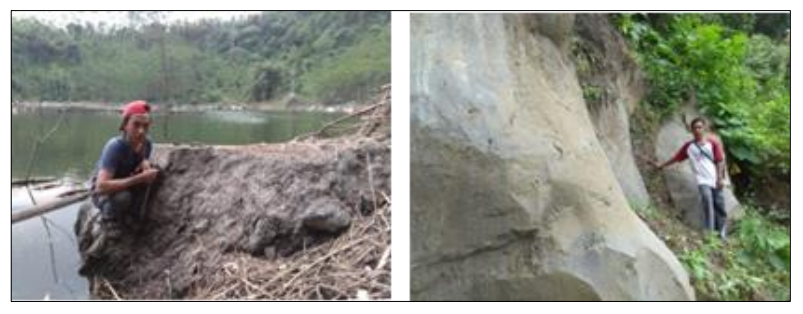

Fig 4. Outcrop of basalt pyroxene of Ranu Lading lava, lava is showing massive and scoria structures.

\subsubsection{Maar Ranu Kembar Lava}

The Ranu is composed by pyroxene basalt lava. Megascopic of basalt pyroxene lava is gray-black, massive structure, hypocrystalline, medium feneric granularity. The observable mineral compositions include plagioclase, pyroxene and olivine embedded in volcanic glass. This basaltic lava outcrop is found at Ranu Kembar (Figure 5).

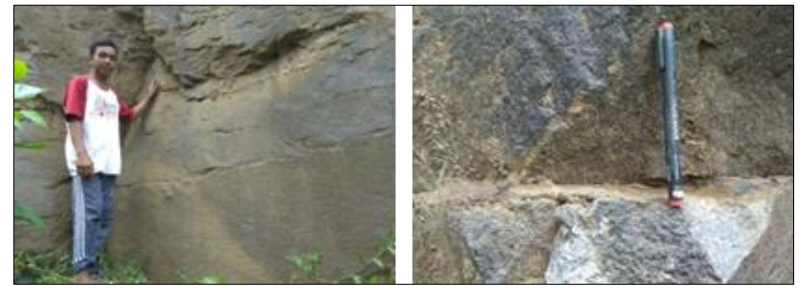

Fig 5. Outcrops of pyroxene basalt lava Ranu Kembar, lava shows massive and scoria structures.

\subsubsection{Tarub eccentric eruption unit (Te)}

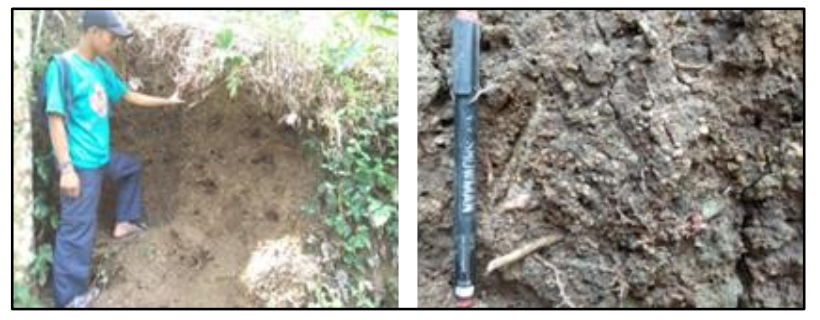

Fig 6. Outcrop of Tarub eccentric eruption unit (Tel) composed by pyroclastic fall deposits are found in Duren village.

This rock unit as a result of the eruption of parasitic cone (bocca) of Tarub volcano. In the study area the rock unit consists of pyroclastic fall deposit (phreatomagmatic deposit). The pyroclastic fall (scoria fall) deposit has a brownish color, lapilli-block/bomb (2-> 64mm), grains supported with subroundedangular. Fragments consist of basalt, armored lapilli, accretionary lapilli in matrix of volcanic ash. Medium 
sorted, graded bedding, and unconsolidated outcrop conditions. The outcrops founded in Sumberweringin and Duren village (Figure 6).

\subsubsection{Lamongan old lava unit (Lit)}

The old Lamongan lava unit (Lit) is the lava unit of the central eruption of Lamongan volcano. This lava is composed of andesite, grayish black and scoria structure. In the megascopic of pyroxene andesite lava is gray-black, scoria structure, hypocrystalline and moderate feneric granularity. The mineral compositions include plagioclase minerals and pyroxene embedded in volcanic glass groundmass. The outcrops encountered in the Papringan village.Lamongan volcano's old flank eruption lava unit (List)

The old eruption lava unit of Lamongan (List) is a rock from the eruption side of Lamongan Volcano. The lithologic unit consists of basalt and pyroxene andesite lava. This lithologies were gray-black with the appearance of surface rocks were rough, sharp and found gas holes (scorias). Description megascopic of basalt lava that exposed in the Papringan village is black, massive and scoria structure with hypocrystalline texture, granularity degree of fine feneric. The mineral compositions include plagioclase, pyroxene and olivine embedded in the volcanic glass groundmass. While the type of lava that was uncovered on Sadeng volcano is an pyroxene andesite. Megascopic description of pyroxene andesite lava is a grayish black, massive and scoria structure. Hypocrystalline texture with medium feneric granularity and the mineral composition of this rock is the plagioclase, pyroxene, embedded in the volcanic glass. The rock unit is exposed also in Salak village.

\subsubsection{Lamongan piroclastic unit (Lp)}

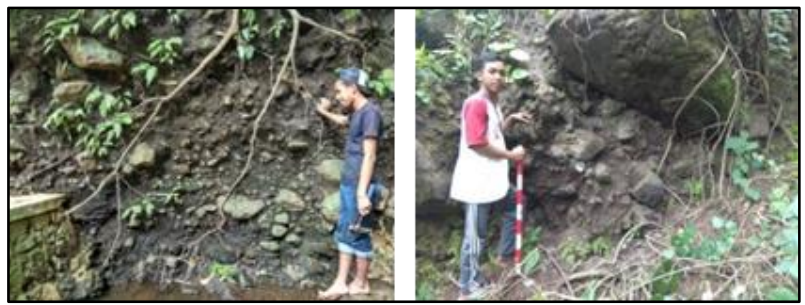

Fig 7. Outcrop of Lamongan pyroclastic deposit consisting of pyroclastic fall (scoria fall) and tuff found at Salak village.

The Lamongan pyroclastic unit (Lp) is pyroclastic rocks that precipitate from the eruption of Lamongan volcano center. The unit of lithology consisting of pyroclastic fall (phreatomagmatic) and tuff (phreatic) deposits. Tuff is a fine ash $(<0.04 \mathrm{~mm})$, brownishcolored, massive structure and unconsolidated outcrop conditions. The pyroclastic fall (scoria fall), brownishcolored, lapilli-bom (2-64 $\mathrm{mm})$ and subroundedangular grain shape. Composed by fragments: basalt, accretionary lapilli, armored lapilli embedded in the matrix consisting of volcanic ash and plagioclase, quartz and pyroxene as microlite minerals. This rock shows medium sorted, massive and graded bedding structures. This rocks unit are founded at Salak, Sumberweringin and Papringan village. (Figure 8). The pyroclastic flow (Figure 8) has a brownish color, lapilliblock/bomb (2-> 64mm), grain supported with the grain shape is subrounded-angular. Composed by basalt block and bomb fragments in the fine volcanic ash matrix. Poorly sorted, massive bedding and outcrop conditions is unconsolidated.

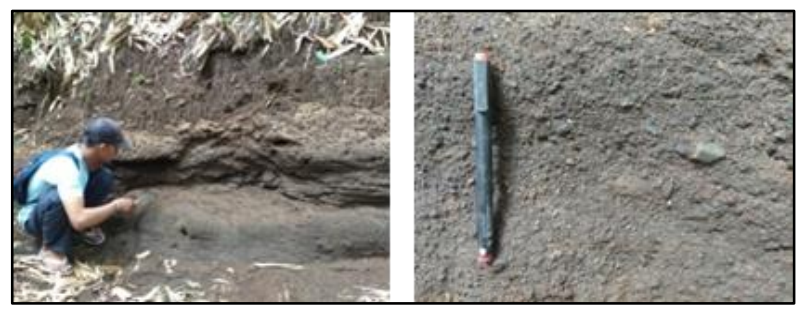

Fig 8. Outcrop of pyroclastic flow deposits at Sumberweringin and Darungan Villages. The pyroclastic flow fragments consist of bomb and block basalt scoria.

\subsubsection{Lamongan volcano's young flank eruption lava unit (Lism)}

The lava unit was a product from eruption side (bocca) of young Lamongan volcano (Lism). The composition of lava was pyroxene basalt. This lava was encountered in the Papringan and Sumberweringin village. The megascopic description of lava was pyroxene basalt. The lava was grayish black, massive structure, scoria with hypocrystalline texture and degree of granularity was fine feneric. The mineral composition consists of plagioclase, pyroxene and olivine embedded in the volcanic glass groundmass (Figure 9).

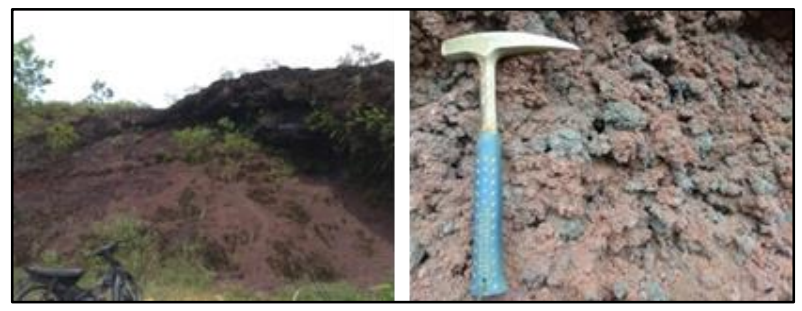

Fig 9. Pyroxene basalt lava outcrop from lava unit of young eruption side of Lamongan volcano exposed at Papringan village, lava showing scoria structure.

\section{Volcanic Rocks}

Interpretation of Lamongan volcano magmatism is obtained from the results of petrographic analysis of volcanic rocks in the study area. The volcanic rocks were represented by 3 samples of pyroclastic fall fragments and 12 lava samples. The result of petrographic analysis was showed that the lavas type consist of pyroxene andesite, basalt and pyroxene basalt. The results of petrographic analysis were presented in Table 1 and can be explained as follows:

\subsection{Pyroxene Andesite}

Pyroxene andesite was found as lavas and were exposed in Lamongan pyroclastic deposit unit (no.58), Lamongan volcano's old flank eruption lava unit (no.50) and Lamongan old lava unit (no.59). Microscopically shown by the 3 samples (Figure 9) shows the pyroxene andesite lava. This pyroxene andesite lava shows the structure of scoria and generally was hypocrystalline, porphyritic, pilotaxitic, aphyric and intergranular 
texture. The phenocrysts (75-85\%) have a size of $0.2-1.2$ $\mathrm{mm}$ consisting of plagioclase, pyroxene (hyperstene, augite) and opaque minerals embedded in the groundmass of volcanic glass and plagioclase microlite. Some opaque minerals are present to inclusion plagioclase and pyroxene.

Plagioclase present about 45-60\% appears colorless, in the form of subhedral-anhedral, long prismatic, 0.2$1.2 \mathrm{~mm}$ in size present as phenochrist and as groundmass of plagioclase type is Andesine (An45An49). Phenocrys of plagioclase generally exhibits albit twining, carlsbad-albit and some individuals shows zoning composition.

Pyroxene (hypersten, augite) is present about 18$20 \%$, as phenochrist and groundmass, thin prismatic or subhedral-anhderal with size $0.2-0.4 \mathrm{~mm}$. Some phenocrysts show corrosion by groundmass and inclusion by opaque mineral.

Opaque minerals are present at about 5-10\%, sometimes present with the groundmass and partially as inclusion in pyroxene.

Volcanic glass was present $15-23 \%$, as groundmass was fine-sized with plagioclase microlite and opaque minerals show intergranular, intersertal and aphyric texture.

\subsection{Basalt}

Basalt is found as lava and is exposed in unit of Tarub maar and Lamongan pyroclastic deposit unit. The unit of Tarup maar is represented by lava no. samples 62 and 103. While the units of Lamongan pyroclastic deposits are represented by fragments of no. samples 23 and 18. and 6. The microscopic of basalts (Figure 10) generally show the scoria structure and hypocrystalline, porphyritic, pilotaxitic, trachytic, aphyric and intersertal textures. The phenocrysts (60\%) have a size of $0.2-1.2 \mathrm{~mm}$ consisting of plagioclase, pyroxene (hyperstene, augite), olivine and opaque minerals embedded in the groundmass of volcanic glass and plagioclase microlite. Some opaque minerals are present inclusion on plagioclase and pyroxene.

Plagioclase present about $40 \%$ appears colorless, in the form of subhedral-anhedral, long prismatic, 0.2-1.2 $\mathrm{mm}$ in size present as phenochrist and as groundmass show plagioclase microlite type Labradorite (An65An69). The phenocryst plagioclase generally exhibits albit twining, carlsbad-albit and some individuals show zoning composition.

Pyroxene (hyperstene, augite) is present about $10 \%$, as phenochris and groundmass, short prismatic or subhedral-anhderal with size $0.2-0.4 \mathrm{~mm}$. Some phenocrysts show corrosion by groundmass and opaque mineral inclusions.

Olivine present $4 \%$, as phenochrist and groundmass, subhedral shaped with size 0.2-0.4 mm.

Opaque minerals are present about 6\%, sometimes in the groundmass and partially as inclusion in pyroxene.

Volcanic glass was present $40 \%$, as groundmass was fine-sized with plagioclase microlite and opaque minerals show pilotaxitic, aphyric and intersertal textures.

\subsection{Pyroxene Basalt}

Pyroxene Basalts were found as lava flows and is exposed in Tarub pyroclastic deposit units (no.sampel $53,55,57)$, Lamongan volcano's old flank eruption lava unit (no.sampel 41) and Lamongan volcano's young flank eruption lava unit (no.sampel 39, 40 and 96). Microscopically shown by the 7 samples (Figure 11) that the lava is pyroxene basalt. These rocks show a porphyritic, intersertal, aphyric and pilotaxitic textures and scoria structure. The phenocrysts (65-82\%) have a size $0.2-1.2 \mathrm{~mm}$ consists of plagioclase, pyroxene (hyperstene, augite), olivine and opaque minerals. Phenocrysts were embedded in the groundmass of volcanic glass and plagioclase microlites. Some opaque minerals were present as inclusion in plagioclase and pyroxene.

Plagioclase present about 40-45\% appears colorless, in the form of subhedral-anhedral, long prismatic, $0.2-$ $1.2 \mathrm{~mm}$ in size present as phenochryst and as groundmass show plagioclase microlite type Labradorite (An63-An69). The phenocryst plagioclase generally exhibits albit twining, carlsbad-albit and some individuals show zoning composition.

Pyroxene (hyperstene, augite) is present about 12$15 \%$, as phenochris and groundmass, thin prismatic or subhedral-anhderal with size 0.2-0.4 mm. Some phenocrysts show corrosion by groundmass and inclusion by opaque mineral.

Olivine present $4-10 \%$, as phenochryst and groundmass, subhedral shaped with size $0.2-0.4 \mathrm{~mm}$.

Opaque minerals are present at about 5-10\%, sometimes clustered within the groundmass and partially as mineral inclusion at pyroxene.

Volcanic glass was present $18-30 \%$, as groundmass was fine-sized with plagioclase microlite and opaque minerals show intersertal and pilotaxitic textures.

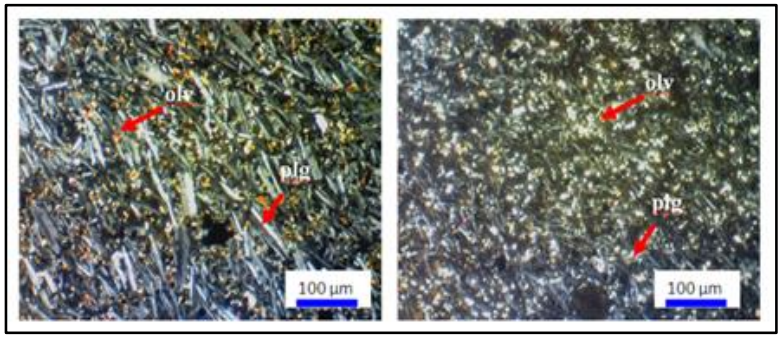

Fig 9. Shows basalt with trachytic texture composed by olivine (olv) and plagioclase (plg) microlite as groundmass. Represented by sample no.sampel 23 and 103 in cross nicol positions.
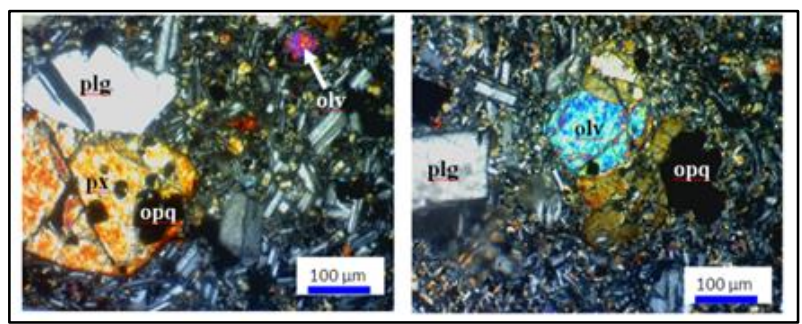

Fig 10. Shows pyroxene andesite lava with intergranular texture composed by plagioclase (plg), pyroxene (px) in groundmass of plagioclase microlite and volcanic glass (vg). It is represented by samples 58 and 5 in cross nicol positions. 


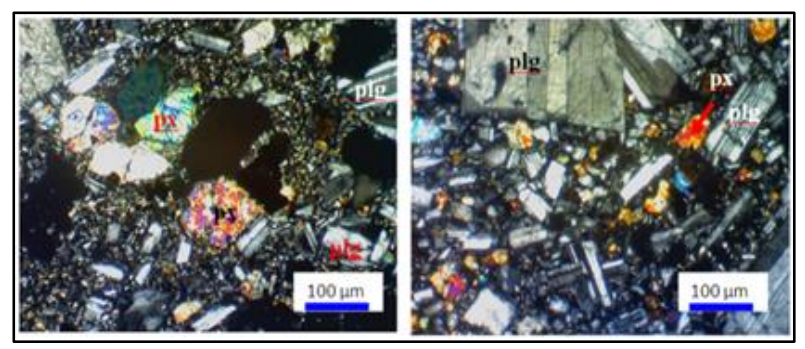

Fig 11. Shows pyroxene basalt lava texture with intersertal, pilotaxitic prepared by plagioclase (plg), pyroxene (px), olivine (olv) and mineral opaque (opq) in plagioclase microlite and volcanic glass (vg) groundmass. It is represented by sample no.sampel 41 and 96 in cross nicol positions.

Table 1. Result of petrography analysis of volcanic rocks at study area

\begin{tabular}{|c|c|c|c|c|c|c|c|c|c|}
\hline $\begin{array}{c}\text { No. } \\
\text { Samples }\end{array}$ & Name of Rocks & & $\begin{array}{l}\text { Name of } \\
\text { Rocks }\end{array}$ & Name of Rocks & olv & $\mathrm{px}$ & plg & opq & $\mathrm{vg}$ \\
\hline 41 & Pyroxene Basalt & Lava & List & intersertal & $\theta$ & $\theta$ & $\theta$ & $\theta$ & - \\
\hline 50 & Pyroxene Andesite & Lava & List & intergranular & & $\theta$ & $\theta$ & $\theta$ & - \\
\hline 18 & Basalt & Fragmen & Tma & intersertal & 一 & $\theta$ & $\theta$ & $\theta$ & - \\
\hline 23 & Basalt & Fragmen & Tma & $\begin{array}{l}\text { pilotaxitic, } \\
\text { trachytic }\end{array}$ & & $\theta$ & $\theta$ & $\theta$ & - \\
\hline 53 & Pyroxene Basalt & Lava & Tma & intersertal & $\theta$ & $\theta$ & $\theta$ & $\theta$ & - \\
\hline 55 & Pyroxene Basalt & Lava & Tma & intersertal & - & $\theta$ & $\theta$ & $\theta$ & - \\
\hline 62 & Basalt & Lava & Tma & intersertal & - & $\theta$ & $\theta$ & $\theta$ & - \\
\hline 57 & Pyroxene Basalt & Lava & Tma & intersertal & $\theta$ & $\theta$ & $\theta$ & $\theta$ & - \\
\hline 103 & Basalt & Lava & Tma & $\begin{array}{l}\text { pilotaxitic, } \\
\text { trachytic }\end{array}$ & - & $\theta$ & $\theta$ & $\theta$ & - \\
\hline 39 & Pyroxene Basalt & Lava & Lism & $\begin{array}{l}\text { pilotaxitic, } \\
\text { trachytic }\end{array}$ & $\theta$ & $\theta$ & $\theta$ & $\theta$ & 一 \\
\hline 40 & Pyroxene Basalt & Lava & Lism & intersertal & $\theta$ & $\theta$ & $\theta$ & $\theta$ & - \\
\hline 96 & Pyroxene Basalt & Lava & Lism & intersertal & $\theta$ & $\theta$ & $\theta$ & $\theta$ & - \\
\hline 6 & Basalt & Fragmen & Lp & $\begin{array}{l}\text { pilotaxitic, } \\
\text { trachytic } 41\end{array}$ & - & $\theta$ & $\theta$ & $\theta$ & 一 \\
\hline 58 & Pyroxene Andesite & Lava & Lp & intergranular & & $\theta$ & $\theta$ & $\theta$ & - \\
\hline 59 & Pyroxene Andesite & Lava & Lit & intergranular & & $\theta$ & $\theta$ & $\theta$ & - \\
\hline
\end{tabular}
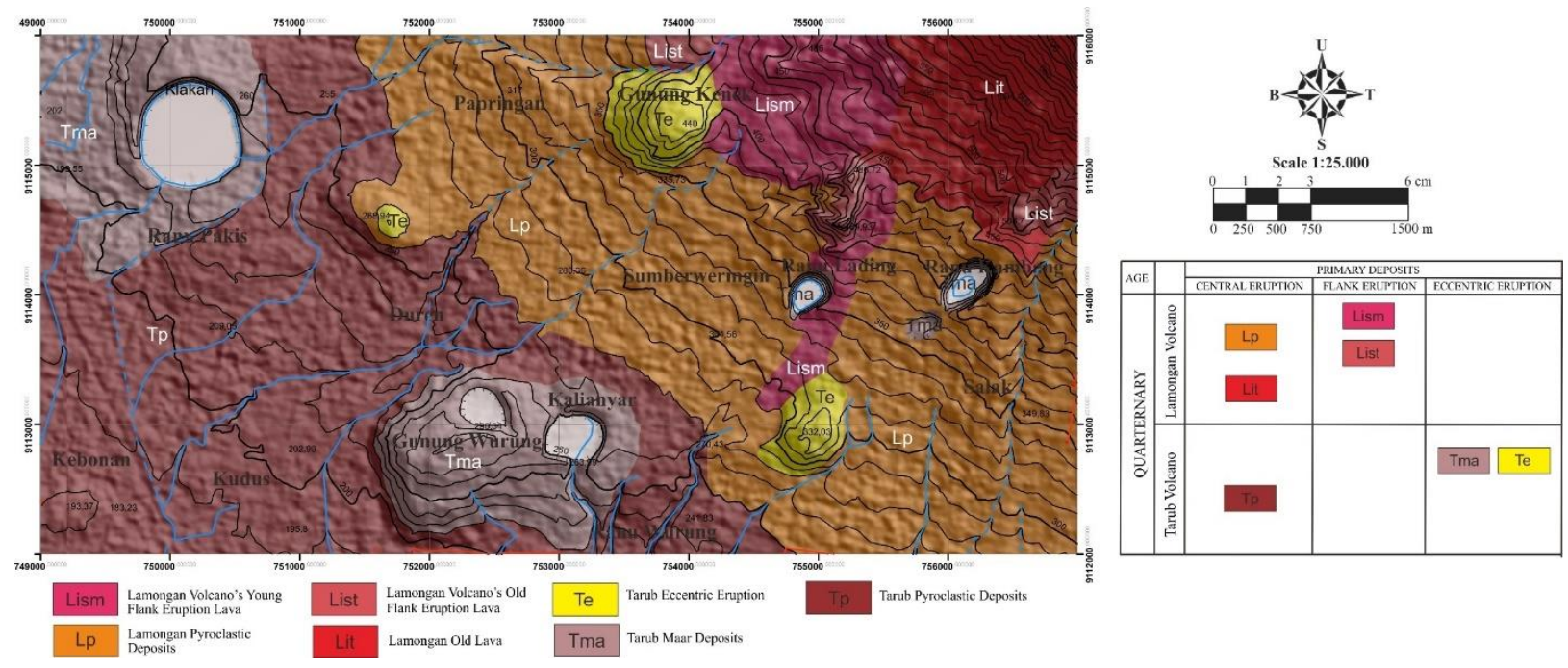

Fig 12. Geological map of Ranu Pakis and surrounding area. 


\section{Magmatism}

The geology Java island was strongly associated with the existence of a magmatic arc from the Sunda subdution zone (Simkin and Siebert, 1994). Deon et al. (2015) Lamongan volcanic rock consists of basalt that derived from different episodes of affusive activity of Lamongan, are mainly composed of Labradorite-Bytownite (An65-An90) plagioclase accompanied by minor olivine and pyroxene. The basalt are characterized by low concentration of $\mathrm{Si}$ element (46-50 wt\% SiO2) and alkali elements (1.62.9 wt\% Na2O; 0.63-2.3 wt\% K2O) and are high in Ca (7-11 wt\% $\mathrm{CaO}$ ). The narrow range in $\mathrm{Si}$ element indicates that the subsequently extruded magmas in this area experienced a relatively low degree of differentiation $87 \mathrm{Sr} / 86 \mathrm{Sr}$ initials range from 0.70430 to 0.70463 . The lava flows and cones span a range of composition from 43-56 wt\% SiO2 and 0.6-2.2 wt\% K2O (basalt-basaltic andesite) gerenally following a calc-alcaline trend (Carn, 1999).

Based on the results of petrography observations in the research area showed that in general volcanic rocks in the study area has a strongly porphyritic texture. This feature according to Ewart (1982) and Wilson (1989) included in island arc volcanic rocks. The phenocryst is abundant about $65-85 \%$, which consists of plagioclase (30-60\%), pyroxene (10-20\%), olivine (4-10\%) and opaque minerals about 5-10\%. The presence of the mineral pyroxene and opaque minerals indicates that the volcanic rocks occur in study area was iron enrichment in line with the process of magma differentiation. Based on the petrographic characteristics of the volcanic rocks at study area show the affinity of volcanic rocks of Lamongan was calc-alkaline (Hughes, 1982).

\section{Conclusions}

The Lamongan volcano is one of the unique volcano in the Sunda arc. The uniqueness is not only the existence of several centers of eruption, but also the variation of eruption litology. This volcano has central eruption deposits, side eruptions or eccentric eruptions (maar and bocca). This volcano's lithology consists of magmatic and phreatomagmatic eruptions, which include pyroclastic flow, scoria fall and phreatic scoria fall/accretionary lapili and pyroxene andesite lava, basalt lava and pyroxene basalt lava. The presence of the mineral pyroxene and opaque minerals indicates that the volcanic rocks was iron enrichment in line with the process of magma differentiation and the affinity of volcanic rocks was calc-alkaline.

\section{References}

Asikin, S.,1974.Evolusi geologi Jawa Tengah dan sekitarnya ditinjau dari segi tektonik dunia yang baru (dissertation). Dept. Teknik Geologi ITB, 103p.

Bemmelen, van, R.W.,1949.The Geology of Indonesia, IA. Government Printing Office, Martinus Nijhoff, The Hague, 792 p.
Bronto, S., Situmorang, T., Effendi, W., 1986.Peta Gunung Api Lamongan, Lumajang, Jawa Timur. Pusat Vulkanologi dan Mitigasi Bencana Geologi, Bandung.

Bronto, S., and Mulyaningsih, S., 2001.Volcanostratigraphic development from Tertiary to Quaternary: A case study.

Cas, R.A.F. and Wright, J.V., 1988.Volcanic Successions Modern and Ancient. Unwin Hyman, London.

Carn, S.A., 1999. Application of Synthetic Aperture Radar (SAR) Imagery to Volcano Mapping in The Humid Tropics: a ca study in East Java, Indonesia. Bull.Volcanol, 61:92-105.

Carn, S.A., 2000.The Lamongan Volcanic Field, East Java, Indonesia: Physical Volcanology, History activity and Hazard. J. Volcanol Geoth Res, 95:81-108.

Carn and Pyle, D.M., 2001.Petrology and Geochemistry of The Lamongan Volcanic Field, East Java, Indonesia: Primitive Sunda Arc Magmas in an Extension Tectonic Setting. J. Petrol.; 4:1643-83.

Deon, F., Foster, H.J., Brehme, B., Wiegand, B., Scheytt, T., Moeck, I., Jaya, M.S. and Putriatni, D.J., 2015. Geochemical/hydrochemical Evaluation of The Geothermal Potential of The Lamongan Volcanic Field (Eastern Java, Indonesia). Geotherm Energy, 3;20, p.1-20, DOI 10.1186/s40517-015-0040-6.

Ewart, A., 1982.The Mineralogy and Petrology of Tertiary Recent Orogenic Volcanic Rocks: with Special Reference to the Andesitic-Basaltic Compositional Range. In Andesites: Orogenic Andesites and Related Rocks. R.S. Thorpe (ed.), Chichester Wiley, 26-87.

Hamilton, W., 1979. Tectonics of the Indonesian region. Geological Survey Professional Paper 1078, U.S. Government Printing Office, Washington, D.C., 345 p.

Heiken, G., 1971.Tuff Rings: example from the Fort Rocks-Christmas lake Valley, south-central Oregon. J.Geophys Res. 1971; 76:561-26.

Hughes, C.J., 1982.Igneous Petrology. New York: Elsevier Scientific Publishing Company, 551 p.

Matahelumual, J.,1990.Gunung Lamongan, Berita Berkala Vulkanologi Edisi Khusus. Direktorat Vulkanologi Bandung, 48 p.

Parkinson C.D., Miyazaki, K., Wakita, K., Barber, A.J., and Carswell, D.A., 1998.An overview and tectonic synthesis of the pre-Tertiary veryhigh-pressure metamorphic and associated rocks of Java, Sulawesi and Kalimantan, Indonesia. The Island Arc, 7, 000-000, 184-200.

Pulunggono and Martodjojo, S., 1994.Perubahan Tektonik Paleogen-Neogen Merupakan Peristiwa Tektonik Terpenting di Jawa, Proc. Geologi dan Geotektonik Pulau Jawa Sejak Akhir Mesozoik Hingga Kuarter, ISBN : 979$8611-00-4,37-50,1-14$

Sayudi, D.S., 1990.Stratigrafi Detail Beberapa Ranu dan Bocca Kompleks G. Lamongan, Kabupaten 
Lumajang Jawa Timur. Proyek Penyelidikan Gunungapi dan Panasbumi Direktorat Vulkanologi Bandung, p.1-36.

Schieferdecker, A.A.G. (Ed.), 1959. Geological Nomenclature, Royal Geol. and Mining Soc. of the Netherlands. J. Noorduijn en Zoon N.V., Gorinchem, 523p.

Sheridan, M. F. and Wohletz, K. H., 1983.Hydrovolcanism: Basic considerations and review. J.Volcanol. Geotherm. Res. 17, 1-29.

Simkin, T. and Siebert, L., 1994.Volcanoes of the World 2nd ed. Tucson: Geoscience Press, p.349.

Soeria-Atmadja, R., Maury, R.C, Bellon, H., Pringgoprawiro, H., Polve, M., and Priadi, B.,1994. Tertiary Magmatic Belts in Java. Journal of Southeast Asia and Petrology, 9, 1327.

Suparka, M.E., 1988.Studi petrologi dan pola kimia kompleks ofiolit Karangsambung utara Luh Ulo, Jawa Tengah, Evolusi geologi Jawa Tengah (Dissertation) Jurusan Teknik Geologi ITB, tidak dipublikasikan, $181 \mathrm{p}$.

Wilson M., 1989.Igneous Petrogenesis a Global Tectonic Approach. Unwin Hillman Ltd, 465 p.

Yudiantoro, D.F. and Yudiantoro, Dewi S., 1992.Endapan Erupsi Hidroklastik Dengan Contoh Maar Ranu Parang Di Kompleks G. Lamongan. Wimaya, no. 14 th.VII, Desember 1992, UPN Veteran Yogyakarta, ISSN 02154579, p.12-21.

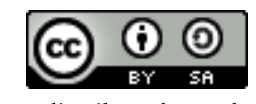

(c) 2016 Journal of Geoscience, Engineering Environment and Technology. All rights reserved. This is an open access article distributed under the terms of the CC BY-SA License (http://creativecommons.org/licenses/by-sa/4.0/). 